\title{
PERANAN KEMAMPUAN NUMERIK DAN VERBAL DALAM BERPIKIR KRITIS MATEMATIKA PADA TINGKAT SEKOLAH MENENGAH ATAS
}

\author{
Ari Irawan \\ Program Studi Teknik Informatika, FTMIPA UNINDRA \\ Jalan Nangka No 58C Tanjung Barat, Jagakarsa, Jakarta Selatan. \\ mascan_89@yahoo.com
}

\begin{abstract}
ABSTRAK
Penelitian ini bertujuan untuk mengetahui apakah terdapat pengaruh kemampuan numerik dan verbal secara bersama-sama terhadap kemampuan berpikir kritis matematika, mengetahui apakah terdapat pengaruh kemampuan numerik terhadap kemampuan berpikir kritis, dan mengetahui apakah terdapat pengaruh kemampuan verbal terhadap kemampuan berpikir kritis matematika. Metode penelitian yang digunakan adalah survey dengan jumlah sampel sebanyak 36 siswa yang terdapat di SMAN 11 Depok. Pegujian hipotesis menggunakan anova dua jalur dan melihat seberapa besar regresi dan korelasinya. Hasil dari penelitian ini adalah terdapat pengaruh antara kemampuan numerik dan verbal secara bersama terhadap kemampuan berpikir kritis matematika, terdapat pengaruh kemampuan numerik terhadap kemampuan berpikir kritis matematika, dan terdapat pengaruh kemampuan verbal terhadap kemampuan berpikir kritis matematika.
\end{abstract}

Kata Kunci : Kemampuan numerik, verbal, berpikir kritis matematika

\begin{abstract}
This study aims to determine whether there is influence of numerical and verbal abilities together the critical thinking skills of mathematics, determine whether there is influence of the numerical skills of critical thinking skills, and determine whether there is influence of verbal ability of the critical thinking skills of mathematics. The method used is a survey with a sample size of 36 students who are at SMAN 11 Depok. ANOVA test of the hypothesis using two lanes and see how big regression and correlation. Results from this study is there is influence between the numerical and verbal abilities together to critical thinking skills of mathematics, there is the influence of numerical ability of the critical thinking skills of mathematics, and there is the influence of verbal ability of the critical thinking skills of mathematics.
\end{abstract}

Keywords: Ability numerical, verbal, critical thinking math

\section{Pendahuluan}

Mata pelajaran matematika menjadi mata pelajaran yang masih dianggap paling sulit bagi sebagian besar siswa, maka dari itu perlu adanya inovasi dan strategi bagi guru untuk membuat pembelajaran matemtika yang dilakukan di depan kelas menjadi lebih menyenangkan dan membuat siswa tidak merasa bosan dalam pembelajaran.

Berkaitan dengan itu dalam pembelajaran matematika perlu adanya pemikiran siswa yang lebih kritis dan mendalam tentang materi yang diajarkan 
oleh guru. karena matemtika merupakan ilmu yang memerlukan konsentrasi dan analisa yang tinggi. Karena berpikir kritis merupakan salah satu kompetensi yang seharusnya dimiliki oleh siswa.

Kemampuan berpikir kritis dan kreatif tergolong kompetensi tingkat tinggi dan dapat dipandang sebagai kelanjutan dari kompetensi dasar, yang di ungkapkan oleh Parwati (2013:65).

Kesulitan mata pelajaran matematika bagi sebagian siswa membuat banyak siswa segan atau malas untuk mempelajarinya. Maka dari itu perlu adanya kesadaran diri bagi guru untuk menciptakan pembelajaran yang menyenangkan dan membuat siswa betah berlama-lama dalam mempelajari matematika. Sementara itu belum adanya tolak ukur bagi siswa sebagai bahan untuk menyadari kekurangan yang dimiliki sehingga siswa akan semakin seulit untuk menentukan titik awal dimana siswa harus mulai belajar.

Permasalahan yang muncul ketika siswa tidak dapat mengikuti proses pembelajaran yang dilakukan oleh guru karena keterbatasan yang dimiliki oleh siswa. Misalnya adalah kurang menguasi operasi dasar hitung matematika seperti perkalian, penjumlahan, pengurangan dan pembagian yang dapat menghambat proses pembelajaran yang dilakukan dikelas. Selain itu adanya keterbatasan kemampuan kosa kata yang dimilki siswa dalam mencerna persolanan matematika dalam bentuk soal cerita yang berimbas pada kurang pemahaman soal yang memerlukan analisis yang lebih tinggi.

Maka datri itu peneliti melakukan pengujian apakah terdapat pengaruh antara kemampuan numerik dan kemampuan verbal dalam peningkatan kemampuan berpikir kritis matematika.

Leonard (2013:65) menyatakan berpikir kritis adalah aplikasi membuat sebuah alasan yang bersifat hati-hati dalam penentuan apakah pendapat itu benar atau sebaliknya atau berpikir kritis itu adalah perubahan pendapat. Senada dengan Irawan (2015:49) yang menyatakan bahwa kemampuan berpikir kritis adalah suatu kemampuan yang dimiliki seseorang dalam menyelesaikan suatu persoalan secara efektif dengan argument yang dapat membantu seseorang untuk menganalisis, mengevaluasi, serta mengambil keputusan tentang apa yang diyakini atau dilakukan. Dari pengertian-pengertian diatas maka dapat disimpulkan bahwa kemampuan berpikir kritis matematika adalah suatu kemampuan berpikir secara mendalam, terstruktur dan analsis untuk menyelesaikan suatu permasalahan dengan menentukan pendapatnya benar atau salah. 
Kemampuan berpikir kritis matematiika ditunjang oleh dua hal yakni kemampuan numerik dan kemampuan verbal. Irawan (2015:49) mengamukakan kecerdasan numerik adalah kecerdasan dalam menggunakan angka-angka dan penalaran (logika) meliputi di bidang matematika, mengklasifikasikan dan mengategorikan informasi, berpikir dengan konsep abstrak untuk menemukan hubungan antara suatu hal dengan hal lainnya. menurut Astuti, dkk (2013) kemampuan numerik merupakan kemampuan yang berkaitan dengan kecermatan dan kecepatan dalam penggunaan fungsi-fungsi hitung dasar.

Irawan (2014:49) mengemukakan bahwa "kemampuan numerik adalah kemampuan dalam menggunakan angkaangka dan penalaran (logika) neliputi bidang matemtika, mengklasifikasikan dan mengkatagorikan informasi, berpikir dengan konsep abstrak untuk menemukan hubungan antara suatu hal dengan hal lainya". Dari pengertian diatas maka dapat disimpulkan bahwa kemampuan numerik adalah kemampuan seseorang dalam menggunakan angka-angka setelah orang tesebut memberikan klasifikasi dengan konsep-konsep abstrak yang dimilikinya.

$$
\text { Rosida dkk }
$$

mengemukakan bahwa "kemampuan numerik yaitu kemampuan yang berhubungan dengan angka dan kemampuan untuk berhitung". Dari pengertian diatas maka dapat disiimpulkan kemampuan numerik adalah kemampuan seseorang untuk melakukan perhitungan dengan angka-angka.

Berdasarkan uraian-uraian pengetian diatas maka dapat disimpulkan kemampuan numerik adalah kemampuan yang dimiliki oleh seseorang untuk menggunakan angka-angka, melakukan perhitungan dan merubah permasalahan uraian cerita menjadi angka-angaka yang selanjutnya dapat dilakukan perhitungan dengan matematika.

Levy \& Ransdell (1996) dalam Kumara (2001:37) menyebutkan bahwa "kemampuan verbal adalah kemampuan menjelaskan pemikiran atau kemampuan mengaitkan berbagai informasi yang diperoleh dan membuat hipotesis". Dari pengetian diatas maka dapat disimpulkan kemampuan verbal adalah kemampuan yang dimiliki seseorang untuk menjelaskan pemikirannya dan mengaikan informasi yang diperolehnya serta dapat membuat suatu hipotesis.

$$
\text { Saregar dkk }
$$

mengemukakan bahwa "kemampuan verbal yang baik diduga memiliki kecakapan yang mensyaratkan keakraban dengan bahasa tertulis maupun lisan untuk menyimak, menelaah isi dari suatu pernyataan, beranimengungkapkan ide, 
gagasan, $\quad$ pendapat, $\quad$ dan

melakukan perhitungan dengan pikirannya,sehingga siswa tersebut dapat menggunakan SPSS anova dua jalur. mengambil suatu kesimpulanyang tepat".

Dari pengertian-pengertian diatas maka dapat disimpulkan kemampuan verbal adalah suatu kemampuan yang dimiliki oleh seseorang dalam bentuk lisan dan tulisan berupa kata-kata yang dapat menjadi alat komunikasi pada diri sesorang dan sebagan bahan pemberi dan penerima informasi yang iberikan oleh seseorang.

\section{Metode Penelitian}

Metode dalam penelitian ini yaitu survey dengan pendekatan kuantitatif dimana sampel yang diambil pada penelitian ini adalah SMAN 11 Depok dengan jumlah sampel sebanyak 36 siswa kelas IPS pada tahun ajaran 2015/2016. Siswa diberikan instrumen berupa tes kemampuan numerik dan kemampuan verbal masing-masing sebanyak 25 soal pilihan ganda. Serta tes kemampuan berpikir kritis matematika sebanyak 8 soal. Dimana masing-masing test tersebut divalidasi dan dihitung reliabilitasnya terlebih dahulu. Selanjutnya ada uji persyaratan analisis data yaitu uji normalitas, homogenitas dan multikolinieritas. Selanjutnya melakukan uji hipotesis menggunakan regresi ganda dan korelasi ganda untuk melihat seberapa besar pengaruhnya. Serta 
Tabel 1. Deskriptif statistik

\begin{tabular}{lrrr}
\hline Test & Mean & \multicolumn{1}{l}{ Std } & \multicolumn{1}{c}{ Varians } \\
& & Dev & \\
\hline Numerik & 20,53 & 2,86 & 8,20 \\
Verbal & 20,50 & 2,62 & 6,89 \\
KBKM & 78,69 & 11,53 & 133,02 \\
\hline
\end{tabular}

Berdasarkan statsistik deskrip dari sampel sebanyak 36 responden memiliki skor minimum pada tes kemampuan numerik adalah 10, kemampuan verbal adalah 13 dan untuuk kemampuan berpikir kritis matematika 33. Sedangkan skor maksimum untuk kemmapuan numerik dan kemampuan verbal masingmasing adalah 25 dan kemampuan berpikir kritis matematika maksimum mendapat skor 97. Dari tabel diatas dapat dilihat skor rata-rata dari kemampuan verbal dan numerik hampir sama begitu pula dengan standar deviasi dan variansnya. Hasil uji hipotesis pengaruh kemampuan numerik dan verbal secara bersama-sama terhadap kemampuan berpikir kritis matematika memperoleh koefisien korelasi sebesar 0,875 sehingga dapat disimpulkan memiliki kontribusi nilai sebesar 0,765 atau sebesar $76,5 \%$ kontribusi kemampuan numerik dan kemampuan verbal secara bersama-sama terhadap kemampuan berpikir kritis matematika. Pengujian hipotesis dengan analisis regresi didapat persamaan regresi adalah

$$
\widehat{Y}=-1,352+1,722 X_{1}+
$$

$2,180 X_{2}$.

Selanjutnya pengujian hipotesis memperoleh signifikansi $0,000<0,05$ maka dapat disimpulkan bahwa terdapat pengaruh yang signifikan kemampuan numerik dan kemampuan verbal secara bersama-sama terhadap kemampuan berpikir kritis matematika. Selanjutnya pengujian hipotesis yang kedua memiliki nilai signifikansi $0,004<0,05$ maka dapat disimpulkan terdapat pengaruh kemampuan numerik terhadap kemampuan berpikir kritis matematika. Hipotesis yang ketiga adalag memiliki nilai signifikansi $0,001<0,05$ maka dapat disimpulkan terdapat pengaruh yang signifikan antara kemampuan verbal dan kemampuan berpikir kritis matematika. Selanjutnya dilakukan dilakukan uji korelasi ganda dimana didapat nilai korelasi sebesar 0,857 sehingga dapat disimpulkan bahwa antara kemampuan numerik dan kemampuan verbal memiliki hubungan yang erat dalam meningkatkan kemampuan berpikir kritis matematika.

Berdasarkan hasil penelitian diatas maka kita dapat melihat saling keterkaitan antara kemampuan numerik dan kemampuan verbal dalam kemampuan berpikir kritis matematika. Artinya semakin siswa memiliki nilai kemamapuan numerik yang tinggi serta 
kemampuan verbal yang tinggi maka akan dapat berimbas pada kemampuan berpikir kritis yang tinggi pula. Karena dalam kemampuan berpikir kritis matematika bukanya hanya kemampuan numerik atau menghitung cepat namun perlu adanaya analisis berupa penguasaan kosa kata dalam hal ini kemampuan verbal karena adanya proses abstraksi kalimat yang diterjemahkan dalam bentuk model matemika memerlukan analisis yang cukup tinggi. Dalam hal ini seperti yang diungkapkan oleh Sunilawati, dkk (2013) guru berperan sangat penting dalam kegiatan pembelajaran, karena guru bertanggungjawab terhadap tujuan pembelajaran yang ingin dicapai secara optimal. Oleh karena itu disamping untuk peningkatakan kemampuan siswa tetapi perlu adanya peningkatan kompetensi guru agar kualitas pendidikan semakin meningkat.

Japa (2014:10) menyatakan berkaitan dengan pembelajaran matematika, banyak kalangan mengakui bahwa aspek pemahaman bagi peserta didik adalah amat penting. Maka dari itu perlu adanya kemampuan yang menjadi pondasi atau dasar untuk siswa sebelum memahami materi ajar yaitu perlu adanya kemampuan numerik dan kemampuan verbal yang dapat meningkatkan kemapuan siswa dalam berpikir kritisnya.
Kemampuan numerik dan verbal dapat ditingkatkan dengan adanya latihan-latihan yang dapat membuat kemampuan menghitung dan kosa kata yang dimiliki semakin meningkat. Karena seiring dengan semakin tinggi tingkat pendidikan yang dilalui secara langsung akan semakin berkembang kemampuan numerik dalam menghitung perhitungan dasar matematika selain itu wawasan kebahasaan semakin banyak kosa kata yang dimiliki.

Oleh karena itu untuk meningkatkan kemampuan berpikir kritis matematika maka perlu adanya peningkatan kemampuan numerik dan kemampuan verbal sehingga dapat menunjang dalam proses berpikir kritis matematika. Karena dalam berpikir kritis matematika terdapat kalimat-kalimat alur cerita yang harus dipahami dan dianalisis. Hal ini sesuai dengan pendapat Simbolon (2014: 232) yang menyatakan bahwa siswa dengan kemampuan verbal rendah akan mengalami kesulitan-kesulitan dalam menyelesaikan masalah.

Dalam proses berpikir kritis matematika diperlukan analisis yang tajam dalam menyelesaikan soal-soal matematika maka dari itu perlu adanya faktor pendukung dalam mengasah kemampuan berpikir kritis matematika. Dalam hal ini perlu adanya peningkatan kemampuan berpikir kritis matematika 
dengan cara memaksimalkan kemampuan numerik dan kemampuan verbal karena dalam pemecahan masalah tersebut.

Seperti contohnya adalah ketika menyelesaikan soal cerita yang memerlukan analisis khusus harus dapat membaca dan memahami soal dengan cermat serta dapat menemukan informasiinformasi penting sebagai pendukung pemecahan permasalahan dan mengetahui pertanyaan dari cerita yang tersaji dalam soal tersebut. Selanjutnya siswa harus dapat mengerjakan soal tersebut sesuai pertanyaan yang diminta dalam soal secara tepat dan cermat berdasarkan informasi yang telah tersaji sebelumnya.

Berpikir kritis bukan hanya menerima informasi begitu saja namun lebih dari itu ada penyaringan informasi yang didapat sebelumnya dan memanfaatkan informasi tersebut untuk menyelesaikan permasalahan yang muncul. Dalam berpikir kritis matematika erat kaitanya dua kemampuan yang seolah-olah saling bertolak belakang namun sebenarnya saling keterkaitan santara satu dengan yang lainya. Kemampuan yang dimaksud adalah kemampuan numerik dan verbal. Menurut beberapa pendapat yang telah dikemukakan sebelumnya kemampuan numerik yaitu berupa kemampuan mengetahui angka-angka dan melakukan operasi hitung sedangkan kemampuan verbal adalah kemampuan penguasaan bahasa berupa kosa kata dan pembentuk kalimat baik lisan ataupun tulisan.

Syahbana (2012:52) menyatakan berpikir kritis dalam belajar matematika merupakan suatu proses kognitif seseorang dalam upaya memperoleh pengetahuan matematika berdasarkan penalaran matematik. Perlu adanya latihan yang terus dilakukan secara berkesinambungan sehingga menciptakan kemampuan yang signifikan oleh karena itu kemampuan berpikir kritis matematika sangat di perlukan sebagai pendukung untuk berpikir yang lebih mendalam secara analisis dan dapat mensimtesis dari berbagai macam teori yang telah ada.

Dalam matematika ada kalimat yang menyatakan dia sebagai operasi dari matematika seperti kata dan yang dapat bermakna penjumlahan misal kan dalam kalimat Andri membeli 3 buah apel dan Andre membeli 2 buah apel maka jumlah apel mereka adalah 5. Jika ditulikan kedalam bentuk matematika arti kata dan yang menunjukan sebagai operasi hitung penjumlahan. Ada begitu banyak kata dalam bahasa indonesia yang mencerminkan operasi hitung pada matematika misalnya adalah selisih, bagi dan kelipatan serta lain sebagainya. 


\section{Kesimpulan}

Berdasarkan hasil dan pembahasan diatas maka dapat disimpulkan kemampuan berpikir kritis matematika dapat ditingkatkan dengan mengasah kemampuan numerik dan kemampuan verbal. Maka dari itu guru perlu mengetahui sampai sejauh mana siswa memliki kemampuan numerik dan kemampuan verbal akan guru dapat mengarahkan siswa agar lebih kritis lagi dalam penyelesaian matemtika.

Saran penulis untuk guru-guru ialah agar dapat mengetahui strategi yang tepat dalam pemberlajaran matematika sehingga dapat memberikan peningkatan kemampuan berpikir kritis matematika siswa. Selain itu siswa hendaknya dapat jujur pada diri sendiri tentang kemampuan yang dimiliki pada kemampuan numerik dan kemampuan verbal yang dimiliki sehingga dapat memberikan gambaran kepada guru tentang bagaimana cara yang tepat untuk memberikan pembelajaran di kelas.

\section{Pustaka}

Astuti, dkk. (2013). Pengaruh pendekatan matematika realistik terhadap prestasi belajar matematika ditinjau dari kemampuan numerik. Jurnal Pendidik Dasar. 3(1).

(http://pasca.undiksha.ac.id/e- journal/index.php/jurnal_pendas/a rticle/view/524) di unduh 28 april 2016.

Irawan, Ari. (2014). Pengaruh kecerdasan numerik dan penguasaan konsep matematika terhadap kemampuan berpikir kritik matematika. Jurnal Formatif, 4(1): 46-55

(2015). Pengaruh kecerdasan numerik dan penguasaan konsep matematika terhadap kemampuan berpikir kritik matematika. Jurnal Formatif, 4 (1): 46-55.

Japa. (2014). Pengaruh pembelajaran kuantum berorientasi pemecahan masalah dalam pembelajaran matematika terhadap penalaran mahasiswa. Jurnal Ilmu Pendidikan, 20 (1): 9-16.

Kumara, Amitya. (2001). Dampak kemampuan verbal terhadap rkspresi tulis. Jurnal Psikologi, (1) : $35-40$

Leonard, (2013). Kemampuan berpikir kritis terhadap prestasi belajar matematika. Mimbar. Pendidikan, I (2): 61-71.

Parwati. (2013). Pengembangan perangkat pembelajaran matematika berorientasi openended problem solving. Jurnal Ilmu Pendidikan, 18 (1): 65-70 
Rosida, Halima dkk. (2002). Hubungan Antara Kemampuan Awal dan Kemampuan Numerik Dengan Hasil Belajar Fisika Siswa SMP. Journal Of Technology Of Education 13(2):12-15. (http://portalgaruda.org/index.ph p?ref=browse \&mod=viewarticle \&article $=107483$ ). Diunduh $16 / 04 / 2015$

Saregar, Antomi dkk. 2013. Pembelajaran Fisika

Kontekstual Melalui Metode Eksperimen dan Demonstrasi Diskusi Menggunakan Multimedia Interaktif Ditinjau dari Sikap Ilmiah dan Kemampuan Verbal Siswa. (http://portalgaruda.org/index.ph p?ref=browse \&mod=viewarticle $\underline{\text { \&article }=157585)} . \quad$ Diunduh $16 / 04 / 2015$

Simbolon, Naeklan. (2014). Pengaruh pendekatan pembelajaran dan kemampuan verbal terhadap kemampuan berbicara bahasa inggris siswa sma negeri 14 dan 21 medan. Cakrawala Pendidikan, XXXIII (2) : 225-235 Sunilawati, dkk. (2013). Pengaruh model pembelajaran kooperatif tipe stad terhadap hasil belajar matematika ditinjau dari kemampuan numerik siswa kelas iv sd. Jurnal Pendidikan Dasar, 3 (1). (http://pasca.undiksha.ac.id/ejournal/index.php/jurnal_pendas/a rticle/view/513) di unduh 28 april 2016.

Syahbana, Ali. (2012). Peningkatan kemampuan berpikir kritis matematis siswa smp melalui pendekatan contextual teaching and learning. EDUMATICA (Journal Pendidikan Matematika), 2 (1) : 45-57 
